\title{
Knowledge-based service industry in a South African university town: The case of Stellenbosch
}

Anita Adendorff \& Ronnie Donaldson

Department of Geography and Environmental Studies, University of Stellenbosch, South Africa.

\section{Abstract}

Knowledge-based service industries, because they are geographically 'footloose', have the potential to contribute to small town and city economies. The university town of Stellenbosch, identified as having a high growth potential, is the location of a growing IT and knowledge-based service sector. Data from questionnaires completed by 104 Stellenbosch companies provided some insight into why they chose this town. Most said that, provided sufficient IT is available, they would be able to function as effectively in another town. This implies that they locate in Stellenbosch as a matter of preference rather than necessity. The paper provides insights into the reasons for the spatial clustering in South African non-metropolitan areas and how companies decide where to locate.

\section{Keywords}

Knowledgel-based sector, location dynamics, university town, Stellenbosch.

\section{Introduction}

The role of knowledge as a catalyst for economic development is synonymous with the New Economy (Amin \& Thrift, 2002). Human capital and flexible production are taking the place of the physical resources and rigid systems of mass production that characterised most of the twentieth century (Aslesen \& Isaksen, 2004; Bryson et al., 2004). In this post-Fordist era, the service sector - the sector responsible for providing intangible commodities primarily produced by people - is increasingly important for driving economic growth. This is particularly true of the knowledge-based service industry. Broadly defined, this industry is a specialised subset of the service sector that provides services involving complex intellectual and knowledge-intensive activities for which the dominant production input is skilled human capital (Aslesen \& Jakobsen, 2007; Shearmur \& Doloreux, 2007).

The significant growth of the service sector, which has been called 'the glue that holds any economy together' (Riddle, 1986:26), is closely related to the new division of labour and fast technological change. Since post-modern society increasingly depends on knowledge-intensive services involving new technology, research, product development and marketing, the New Economy may also be referred to as the knowledge or learning economy (Castells, 2000; Aslesen \& Isaksen, 2004; Harloe \& Perry, 2004).

Firms whose production processes are flexible, responding to the increased demand for specialised services, rapid technological change and dynamic markets, are gaining a competitive advantages (Coffey, 1995; Daniels \& Bryson, 2003). The result has been increased investment in the creation, transfer and application of intellectual capital, to the detriment of investment in physical goods (Florida, 1999; Castells, 2000; Bryson et al., 2003). 
According to Yigitcanlar et al. (2008:63), the evolution of the 'knowledge city' has meant 'developing a path towards a more viable, vibrant, and sustainable form of urban development'. However, since 2000 a regional approach to the knowledge-based economy (Clark, 2010; Uyarra, 2010) has included policy issues such as 'promoting region-specific clustering; building habitats for innovation and entrepreneurship; collective learning processes and innovation networks; building a stock of social capital; and promoting local and global networks' (Park, 2001:29). Some believe that developments in information and communication technologies (ICT) have allowed knowledge-based firms the freedom to locate in peripheral areas. The contradiction between the 'footloose' nature of these industries ${ }^{1}$ and their spatial concentration in metropolitan centres is an issue that needs investigating in the South African context, where economic policy initiatives are increasingly taking regional development perspectives (Cornelissen, 2006).

According to the World Bank's (2008) knowledge assessment methodology report, South Africa ranked 55th out of 140 countries on the Knowledge Economy Index. Ensuring that the country keeps up with global technological trends and fully exploits comparative advantages, including usage of ICTs, is mentioned as very important in the post-Mbeki ANC Government's Medium Term Strategic Framework (The Presidency, Republic of South Africa, 2006). Specific measures are planned for supporting innovation and technological development. Globally, specialised activities such as innovation and experimentation are typically located in metropolitan or secondary urban areas where highly skilled labour, good communication networks and high-quality living environments are available.

In South Africa the current spread of innovation and experimentation is limited primarily to the metropolitan areas and a number of secondary city or town areas in which universities and research institutions are located, such as Potchefstroom, Pietermaritzburg, Grahamstown and Stellenbosch (The Presidency, Republic of South Africa, 2006). If South Africa is to compete successfully in the global economy while at the same time preventing increases in regional disparities, we need to understand the nature and extent of the country's knowledge-based service sector. This includes identifying the locational dynamics that shape the geographic concentration of industries, and harnessing the service industry's contribution to economic development in a way that will support cities, smaller towns and peripheral localities. Academic research into the nature and extent of local knowledge-based service industries is still sparse. This paper helps to supply the deficiency by discussing the dynamics behind the knowledge-driven industry's decision to locate within a region peripheral to a large metropolitan area, using a case study in the Stellenbosch area.

\section{Review of the knowledge-based industry literature}

In this paper the term 'knowledge-based service industry' refers to a specialised subset of the service sector that provides services involving high-order complex intellectual and knowledge-intensive activities for which the dominant production input is skilled human capital (Shearmur \& Doloreux, 2007). Daniels (1993) differentiates the more 'durable' services, such as those dealing with management and business consulting, computers and engineering, from the less knowledge-intensive, more 'perishable' services such as those dealing with security, office cleaning and deliveries. In this paper the terms 'knowledge-based', 'knowledge-intensive', 'knowledge-driven' and 'high-order' services are used interchangeably. 
The laws that govern the geographic distribution of service industries generally differ from those that govern the distribution of manufacturing industries (Rogerson, 2001, 2002). In his theory of cost minimisation, Weber suggested choosing a manufacturing location according to whether the costs will be lower for transporting either the raw materials or the finished products (Bale, 1981). For knowledgebased service industries, however, production factors such as transport, product shipment and raw materials have become almost obsolete and spatial distribution is now primarily a consequence of market orientation and a heavy dependence on a highly educated workforce (Rogerson, 2001; Bryson et al., 2004; Florida, 2005).

However, Weber's theory did recognise the potential of agglomeration economies and labour availability as a determinant of manufacturing location (Bale, 1981). In Lösch's (1954) market area theory, a hierarchy model of marketplaces with surrounding spheres of influence predicts that industries will locate where their profits are maximised, though the theory's focus on market demand makes it slightly more applicable to tertiary services. Porter introduces the concept of clusters, defined as 'geographic concentrations of interconnected companies and institutions in a particular field' (1998:78), and Lawton Smith et al. (2001) distinguish between clusters and linkages, with the latter extending beyond spatial proximity to emphasise relational processes such as face-to-face contact and shared cultural backgrounds that facilitate knowledge flows and technology transfers between closely situated firms (Daniels \& Bryson, 2003).

The clustering together of high-order service activities allows for backward linkages that reduce delivery costs and promotes face-to-face consultation, inter-firm networks and knowledge spillovers (Rogerson, 2002; Florida, 2005). Marshall first explained centralised geographic patterns as being the result of these beneficial agglomeration economies associated with the spatial concentration of service firms (Castells, 1991; Coffey \& Shearmur, 1997; Rogerson, 2002; Florida, 2005). Florida (2005) emphasises the importance of highly skilled individuals as drivers of innovation and economic growth by arguing that concentrations of these individuals not only motivate firms to locate within an existing cluster but also constitute the greatest driving force behind the formation of clusters. Other agglomeration economies include suitable office accommodation, state-of-the-art telecommunication services and reliable transport and infrastructure (Bryson et al., 2004).

The location of service activities is important because they help to increase productivity and drive national and local economic development (Lublinski, 2004). Some scholars have been optimistic about the potential of the service economy to direct economic growth in underdeveloped, small or nonmetropolitan regions (Coffey \& Shearmur, 1997). This optimism is based on the assumption that highorder service industries are no longer subject to locational constraints because advances in ICT now allow them to choose their prime locations (Coffey \& Shearmur, 1997; Rogerson, 2001). Despite this perception, international evidence confirms that there are 'enormous disparities in high order service concentration along the rural-urban continuum' (Coffey, 1995:76). The role that ICT development plays in loosening the locational restrictions of service industries is ambiguous. On the one hand, it is claimed that telecommunications can obviate the necessity for face-to-face contact with clients, allowing the decentralisation of high-order service industries; on the other, that these industries are not as 'footloose' as believed, since numerous studies illustrate the tendency of technology to promote the concentration of service activities in cities due to agglomeration economies (Coffey \& Shearmur, 1997; Bryson et al., 2004). 
There is an established trend for high-order service activities to concentrate within a limited number of large metropolitan areas. Cities are ideal locations for maximising agglomeration economies since they can supply highly skilled labour, research institutions and universities that educate labour and create the knowledge on which service industries depend. The concentration of service firms is also motivated by their need to be situated close to their clients in the big cities who prefer face-to-face contact (Daniels \& Bryson, 2002; Aslesen \& Isaksen, 2004). Although urban clustering remains the dominant trend, Coffey $\&$ Shearmur note that, provided sufficient ICT is available, 'individual high-order service establishments are able to function quite effectively in small places, often serving national markets' (1997:417).

Companies in small towns are often the result of spin-offs from larger firms or the initiatives of individuals who were formerly partners or employees of city-based firms (Daniels \& Bryson, 2003). Numerous authors ascribe the growth of service industries in small towns to the better quality of life these areas afford professionals. Provided rural communities have access to advanced ICT and transport infrastructure, knowledge-based services can play an integral part in the economic development of small towns and rural communities. Research suggests that the presence of large pools of skilled labour acts as a catalyst for the establishment and growth of regional clusters of firms (Rogerson, 2001). The geographic distribution of a highly educated workforce is considered the most significant determinant of the location of high-tech industries in the UK (Keeble in Rogerson, 2002). Castells (1991) confirms this trend for the US, where research shows that labour is the most important production factor. This dependence on high-skilled labour places restrictions on most knowledge-based service industries, meaning that they are not as 'footloose' as is claimed.

Rogerson (2002) also emphasises the role of environmental pull factors in companies' choice of location. Klaus (2004:5) notes that the 'central question' is no longer where 'enterprises settle' but where 'qualified and highly qualified labour settle'. Pleasant scenery, an environment that offers many cultural activities, good climate, a variety of educational institutions and close proximity to recreation amenities are some of the factors believed to increase the quality of life and consequently considered necessary in a potential business location if it is to attract suitably educated knowledge workers. Florida's creative capital theory (2005) says that creative individuals are the drivers of regional economic growth. The theory emphasises the tendency of highly educated individuals, such as scientists, engineers, university professors, designers, architects, researchers, analysts, and high-tech, financial, legal and business management professionals, to locate in areas that match their personal preferences. The mobility of such individuals puts pressure on regions to produce the environments and infrastructure necessary to attract and keep them.

\section{The knowledge-based service sector in South Africa}

With the advent of the new democratic era in 1994 South Africa was re-admitted to the competitive global economy after two decades of exclusion. Castells (1998) and Rogerson (2000) expressed optimism about of the way technological linkages in South Africa could help incorporate the African continent into the IT revolution of the New Economy. A Trade, Industry and Investment Review by SADC (2006) confirmed that the South African economy with its efficient financial system was the most advanced on the African continent.

Nationally, the shift of local economic development responsibilities to provincial and local government has increased the competition between provinces to attract footloose investment (Harrison, 1994; Rogerson, 2000). Urban competition has been cited as a major cause of the widening gap between 
regional economies. Harrison (1994) highlights the inability of lagging regions to engage in entrepreneurial strategies, resulting in increased regional disparities and the further marginalisation of peripheral localities. The incorporation of knowledge-based service industries into the economies of peripheral localities could thus be of crucial importance in ensuring their sustainability.

The knowledge-based services sector has become one of the principal contributors to economic growth in South Africa, as evidenced by the fact that the leading contributions to the national GDP in 2004 were from community, social and personal services (R194 175 million) and finance and real estate and business services (R194 093 million). In 2001, finance and real estate and business services replaced the manufacturing sector as second largest contributor to GDP. The same trend could be seen in the Western Cape, where the services sector contributed $65 \%$ to the province's economy and created most of the new jobs (WCPG, 2006).

Although the service sector contributes significantly to the economic growth of South Africa, these industries are not evenly distributed. Rogerson states that 'it is necessary to understand the dynamics of knowledge-based activities as potential drivers of the national space economy' and that the growth in knowledge-based activities warrants 'a new logic of economic location' that transcends traditional theories of industrial location (2001:34). Rogerson (2001) describes the geographical agglomeration of related knowledge-based activities and industries as 'smart regions', with the potential to be influential growth nodes and drivers of economic and spatial development.

\section{Stellenbosch University and the knowledge-based service industry in Stellenbosch}

Angelis et al. argue that the presence of a university in a region may act as an initiator or supporter of knowledge-based industries (2007:1). Varga states that 'anecdotal evidence suggests that under certain conditions a research university can play a central role in generating economic growth for the region where it resides'. He refers to the well-known success story of the Hewlett-Packard Fortune 500 company that originated when Stanford University professor Fred Terman encouraged his student, Bill Hewlett, to start a company on the basis of an idea in Hewlett's master's thesis project - 'probably the first university spin-off firm in history' (2002:1).

The university town of Stellenbosch, with a population of 120000 (Stellenbosch Municipality, 2007), was an obvious choice for a case study. It is situated in the Western Cape Province of South Africa, less than $50 \mathrm{~km}$ from Cape Town, and is surrounded by fertile agricultural land, largely under vineyards. Established in 1679, it is the oldest town in South Africa and its rich historical and cultural heritage, along with its scenic natural surroundings, has led to a flourishing tourism industry. It is internationally recognised for its university, considered to be one of the top four research universities in the country. ${ }^{2}$ The town's tourism and agricultural sectors are thriving, but the highest contribution (27.1\%) to GDP per region in 2004 was made by the financial and business services sector, followed by the manufacturing, wholesale and retail trade, and catering and accommodation services. The Stellenbosch Municipality's Integrated Development Plan (2007) recognises the IT and communication industry as having great potential for economic growth.

\section{Study methodology and findings}

A survey was carried out in 2008. Since data sources for knowledge-based services in Stellenbosch were inadequate, the researchers constructed their own database from which to select the research sample. To 
determine which businesses would qualify for inclusion in the case study, the Standard Industrial Classification index was used as the primary guideline. A questionnaire was distributed to 329 identified businesses and 104 were received completed. The following discussion of the findings includes a description of the prevalent business categories, branch types and the average time that the businesses had been operational in the study area. This is followed by a detailed analysis of factors that influenced their decision to locate in Stellenbosch.

\subsection{Knowledge-based categories}

Businesses were asked to categorise their organisation into the most appropriate knowledge-based activity group according to a list loosely based on the categories defined in the Standard Industrial Classification index. The results showed a fairly even distribution of business types, with a slightly higher number in the Financial Intermediation and Computer and Related Activities sectors, which each constituted approximately $10 \%$ of the total number of participating businesses (see Figure 1).

Most of the 104 were single branch businesses with no other operational offices outside Stellenbosch $(63 \%)$. A further $14 \%$ were national branches and $11 \%$ were national head offices. The fact that there were slightly more international head offices $(8 \%)$ than international branches $(5 \%)$ emphasised the necessity to determine why these businesses chose Stellenbosch. It was interesting to see the high proportion of head offices, both national (18\%) and international (36\%), in the category Computer and Related Activities. The dominance of head offices in this category supports the argument by Rogerson (2000) that IT industries play an important part in stimulating investment in a town.

The average business in the survey sample had been in operation for between 9 and 14 years, i.e. had been established between the beginning of 1994 and the end of 1999, possibly reflecting the newly democratic South Africa's reintroduction into the global economy but also the effect of significant reductions in company tax as part of the overall tax reform measures implemented by the National Treasury at this time (Manuel, 2002). It was noted that there had been an increase in the number of newly established international head offices, with three of the eight having been established only since 2004 (see Table 1), and that two of these three were in the Computer and Related Activities category. In addition, four of the overall eight international head offices were in this category, further supporting Rogerson's (2000) prediction of the potential of IT industries to stimulate regional economic development.

International experience has shown certain factors to be important for ensuring the sustainability of the service industry in the new global economy. The degree to which these factors contribute to the success of the business may vary substantially according to physical location, so they affect a company's location decision to varying degrees. Table 2 shows the ratings for eight factors in terms of their contribution to the successful performance of the study sample's core business activities.

A highly educated workforce and face-to-face consultation with clients were rated by just over half of the sample as factors crucial to their business's success. This suggests a certain degree of dependence on locations close to clients.

However, a distinction must be made between face-to-face consultation and proximity to clients. The latter, indicated as a separate factor, was rated as important by a third of participants but crucial by only $16 \%$. The discrepancy between these two seemingly related factors could be linked to the increasing 
tendency of businesses to follow project-based approaches with short to medium term time limits. Though face-to-face consultation with important current clients is of crucial importance in these situations, the temporary nature of these business relationships does not necessarily warrant locating the business physically close to the client.

The availability of the latest ICT was rated as crucial by $39 \%$ of businesses and important by $36 \%$. Service industry literature casts no doubt on the fundamental relationship between knowledge-based service industries and the availability of advanced IT. Most of the businesses in the sample that said R\&D was essential to their operations were in the categories Technological Development or Computer and Related Activities, which is to be expected given their specific dependence on innovative fastchanging technologies. Proximity to competitors was the only relatively insignificant factor, rated by just over half of participants as not important at all. The database of Stellenbosch knowledge-based service industries compiled for this study showed that the town has a high-tech industry cluster made up of only a fairly small number of businesses. It would thus make sense for those businesses that rated proximity to competitors as crucial to their operation to locate themselves in cities where such businesses are more numerous.

\subsection{Locational factors}

Twenty-five factors were identified that could contribute to the choice of Stellenbosch as an ideal business location. The factor rated most important was the fact of the town being the business owner or key role player's home town at the time the business was established. Almost half $(45 \%)$ of the businesses rated this as crucial in their choice of location and a further $40 \%$ as beneficial (Table 3 ). On average, primary branches for whom Stellenbosch was their first physical location rated this factor as of greater importance than did secondary branches and businesses that had relocated to Stellenbosch from elsewhere.

The relationship between factors reflecting personal choice in terms of an owner's place of residence and factors influencing business location decisions is not always easy to see, particularly in the case of smaller and single branch businesses. Four other factors ranking among the top 10 reasons for locating a business in Stellenbosch were related to the quality of life associated with the town: beautiful natural surroundings, a better quality of life for employees, the availability of good primary and secondary education for the employees' children, and safety in terms of relatively low crime rates. In this regard the Stellenbosch case study strongly supports researchers such as Rogerson (2001) and Harloe \& Perry (2004) who ascribe the growth of service industries in particular towns to factors pertaining to quality of life.

More recently, attention has shifted to 'another aspect of spatial proximity, relating to the perceived benefits of industrial agglomeration and spatial proximity between firms' (Amin \& Cohendet, 2005:467). There is a debate in the service sector literature between proponents of the theory that service-based industries have become 'footloose' and those who believe that these industries still depend on face-to-face consultation, which obliges them to continue locating close to clients. Supporting the latter claim, well over half of this sample $(58 \%)$ rated face-to-face consultation as crucial to their business (Table 2). In further support, almost a quarter of the sample (23\%) rated proximity to their most important business clients as crucial, and one fifth $(21 \%)$ rated proximity to the majority of their clients as crucial. 
These two factors also ranked fifth and sixth respectively in their overall importance. However, the relationship between proximity to clients and the importance of face-to-face client consultation is unclear. Fewer than $30 \%$ of the businesses that rated face-to-face consultation as crucial to their success rated proximity to the majority of clients as a crucial consideration in their decision to locate in Stellenbosch. Furthermore, less than a third of the businesses that depended heavily on face-to-face consultation rated proximity to their most important clients as crucial in this decision. It can thus be deduced that although most of the businesses in the sample believed the successful operation of their business depended on face-to-face consultation, the locational decisions of most were not dictated exclusively by proximity to clients.

It is interesting to note, however, that both client-related factors were rated as of greater importance by secondary branches and relocated businesses than by those for whom Stellenbosch was their first choice of location. This suggests that many companies establish secondary branches or relocate their businesses to Stellenbosch to be closer to their client base. In general, factors pertaining to client proximity were also given higher overall importance ratings by national and international branches than by head offices. This is probably because branches are usually established close to specific clusters of clients, whereas a head office's purpose is more often mainly to carry out general administrative functions and not primarily to offer services to clients.

On average, proximity to the majority of clients was rated the single most important factor by national branches. International branches also rated proximity to their most important clients and to useful business networks as the most importance considerations in locational decision-making. Table 4 supports these findings. It shows that the clients of national and international branches were either in Stellenbosch (23\% and 30\% respectively) or the immediate surrounding area (36\% and $24 \%$ respectively), but that just over half $(52 \%)$ of the clients of national head offices were in other provinces and $65 \%$ of the clients of international head offices were in other countries. Predictably, the clients of branches with a single operational office in Stellenbosch were largely located within Stellenbosch itself $(41 \%)$.

In the new knowledge economy, natural resources and manual labour have taken a back seat in favour of intellectual capital and a highly skilled workforce (Florida, 1999; Anselin et al., 2000; Harloe \& Perry, 2004). A critical consideration in choosing a business location is therefore the availability of a highly skilled workforce. Once again this important requirement of the sample of Stellenbosch businesses supports overall findings in the service industry literature. Of the 10 factors considered most important in choosing Stellenbosch as business location, three were related to the availability of a highly skilled workforce. The first was the fact that Stellenbosch is a highly suitable location for attracting specialist employees. This was ranked overall the fourth most influential factor (see Table 3). Once again it is noteworthy that this requirement is closely related to the desired quality of life often associated with smaller towns.

The responses of the Stellenbosch businesses confirm that the town possesses many of the specific environmental pull factors required to attract highly skilled employees. Examples include beautiful natural surroundings, good quality of life, cultural amenities, an innovative environment and availability of good educational institutions. The potential to attract employees is a crucial consideration in the choice of business location. The second factor related to the availability of a highly skilled workforce that was rated important by the sample was the direct availability of highly skilled university graduates in Stellenbosch. This factor, ranking seventh in overall importance, was regarded as crucial by almost a fifth of the businesses in the study sample when considering this town as a potential location. 
The third skilled workforce-related factor, ranked eighth most important in influencing locational decision-making, was Stellenbosch's excellent pool of highly educated specialists. International branches and international head offices in particular rated Stellenbosch's existing pool of educated specialists and the town's potential to attract new employees as two of the most important considerations in their decision to locate in the town. Taking into account the significant influence of the workforce on the service industry's geographic distribution, it is noteworthy that Stellenbosch is considered to be a good location both for its existing labour force and for having many of the pull factors that attract highly skilled employees from other areas.

Business networks were also ranked in the top 10 most influential factors by most of the sample (58\%). This is an important consideration when choosing a business location, but we must distinguish between inter-business competition and inter-business collaboration. Competition occurs where businesses are in the same industry and provide the same type of service. Collaboration becomes possible where businesses are related, possibly but not necessarily within the same industry, and interaction allows for the development of mutually beneficial networks. It was interesting to see that international branch offices in particular chose business networks as one of the most influential factors in their decision to locate in Stellenbosch. Although proximity to clients played a significant role in the sampled businesses' decision to locate in Stellenbosch, 65\% of the sample rated proximity to competitors as unimportant (see Table 3).

Being situated at a prestigious address or office park also rated among the top 10 factors determining business location. More than half the sample rated it as beneficial at the very least. To discover whether specific areas in Stellenbosch could be directly linked to perceptions of prestigious location, an 'average nearest neighbour' analysis was done, using ESRI ArcMap. The results showed that those businesses that rated a prestigious address as crucial in their choice of Stellenbosch were indeed clustered in certain geographical areas in the town, particularly the historical part of Stellenbosch's CBD and Technopark office park. The oldest and most prestigious part of Stellenbosch is the area around Dorp and Church Streets which reflects the town's heritage. Technopark, on the other hand, is closely related to high technology service industries, its initial purpose having been to house spin-off projects and commercialised research initiatives driven by Stellenbosch University.

Castells and Hall (in Borja \& Castells, 1997) draw attention to the phenomenon of geographically concentrated technology-driven industries in an innovative milieu, known as 'technopoles', which often take the form of science parks and have a close connection with research institutions. Although Technopark has since its inception attracted a variety of industry types, most of which have no direct link to Stellenbosch University, many of its businesses still fall within the knowledge-based service sector, with numerous Computer and Related Activities industries and Technological Development and Engineering consultancies still collaborating with the University to varying extents. Businesses across various service industry categories commented on the high status associated with an office in Technopark, where the prevalence of professional industries associated with advanced technology and innovation allows for inter-firm collaboration and networking opportunities and attracts new clients.

Convenient transport links and infrastructure are one of the agglomeration economies that encourage firms to cluster together (Bryson et al., 2004). The importance of both IT and transport infrastructure is emphasised in various studies that have looked at how service industries can contribute to the economic development of small towns by exporting their services to other areas (Beyers \& Lindahl, 1996; Coffey \& Shearmur, 1997; Bryson et al., 2004). As has been mentioned above, large proportions of the clients of the sampled national head offices and international branches and head offices were in other provinces and other countries. Although the service industry does not depend on physical resources that need to be 
transported to markets, its dependence on face-to-face consultation, as evidenced by this study, suggests it does need good transport networks. Stellenbosch is conveniently located between the N1 and N2 major highways and has a Metrorail station allowing access to Cape Town. In addition, the town is situated less than $40 \mathrm{~km}$ from Cape Town International airport and also boasts a small local air field. Though convenient transport infrastructure was outranked by many other factors with regard to how much it contributes to the successful operation of Stellenbosch businesses, 59\% of the businesses did consider it to be at least necessary to the successful operation of their businesses (see Table 2).

When considering its impact on business location decisions, transport infrastructure ranks relatively low in comparison with other factors. It is important to note, however, that most of the study participants were single branch businesses and that most of their clients are situated in Stellenbosch. The influence of existing transport links on business location decisions was regarded as much more significant by the international head offices that had high percentages of clients in other provinces and abroad. They specifically mentioned proximity to both local and international airports as a beneficial aspect of the town's location. This study's finding that transport infrastructure was of considerable importance in the operation and location decisions of knowledge-based service industries challenges the belief that the service sector is footloose. Although it was not the primary concern of the Stellenbosch service industries in the study, the importance of convenient transport links cannot be underestimated, particularly when it comes to connecting industries with clients to allow face-to-face consultation.

\section{Conclusion}

This study identified several factors of particular importance to a sample of Stellenbosch knowledgebased service businesses when deciding where to locate. It shed light on some characteristics of the town that made it attractive to this particular economic sector and showed that it was combinations of a few factors rather than one dominant factor that influenced their decisions. Further research could compare the advantages of Stellenbosch with other similar sized towns close to Cape Town. Most of the businesses sampled in this study said that, provided sufficient IT was available, they would be able to function as effectively in another town. This implies that, in spite of the numerous factors that influence location choice, most of these businesses had located in Stellenbosch as a matter of preference rather than necessity. The town appears to offer a combination of advantages that is particularly attractive to knowledge-driven service industries.

The provincial 2004 Growth Potential Study (Van der Merwe et al., 2004) and the revision of this study by Van Niekerk et al. (2011), and the Western Cape Provincial Government's Provincial Spatial Development Framework, which is in the process of being drafted, provide a rationale for the focusing of fixed-infrastructure investment in the so-called leader settlements. Ideally, intervention strategies should be formulated to capitalise on the important locational factors for knowledge-based industry in Stellenbosch. The South African literature and government policies pertaining to the knowledge-based service sector seem to reflect, on a smaller scale, international literature and policies dealing with similar issues. There is need for further research on the potential of the knowledge-based service sector to improve South Africa's competitiveness in the New Economy.

The findings of this study suggest four research themes: how the location decisions of knowledge-based service industries in different non-metropolitan local contexts contribute to local, provincial and national economic development; how knowledge-based industries in small to medium-sized towns and peripheral regions can help to decrease disparities between urban and rural centres and ensure the sustainability of the latter; how collaboration between universities and knowledge-based industries in other medium- 
sized towns and also larger urban centres can contribute to local and regional economic development; and how existing and potential collaboration efforts between local governments and the knowledgebased service sector industries could stimulate economic development.

\section{Acknowledgements}

The authors gratefully acknowledge the financial support of the South Africa-Netherlands Research Programme on Alternatives in Development (SANPAD).

\section{Notes}

${ }^{1} \mathrm{~A}$ 'footloose' industry is one that can be set up at any location without being affected by factors such as resources or transport.

${ }^{2}$ See http://veldfiremedia.com/index.php/stellenbosch-university. 
Figure

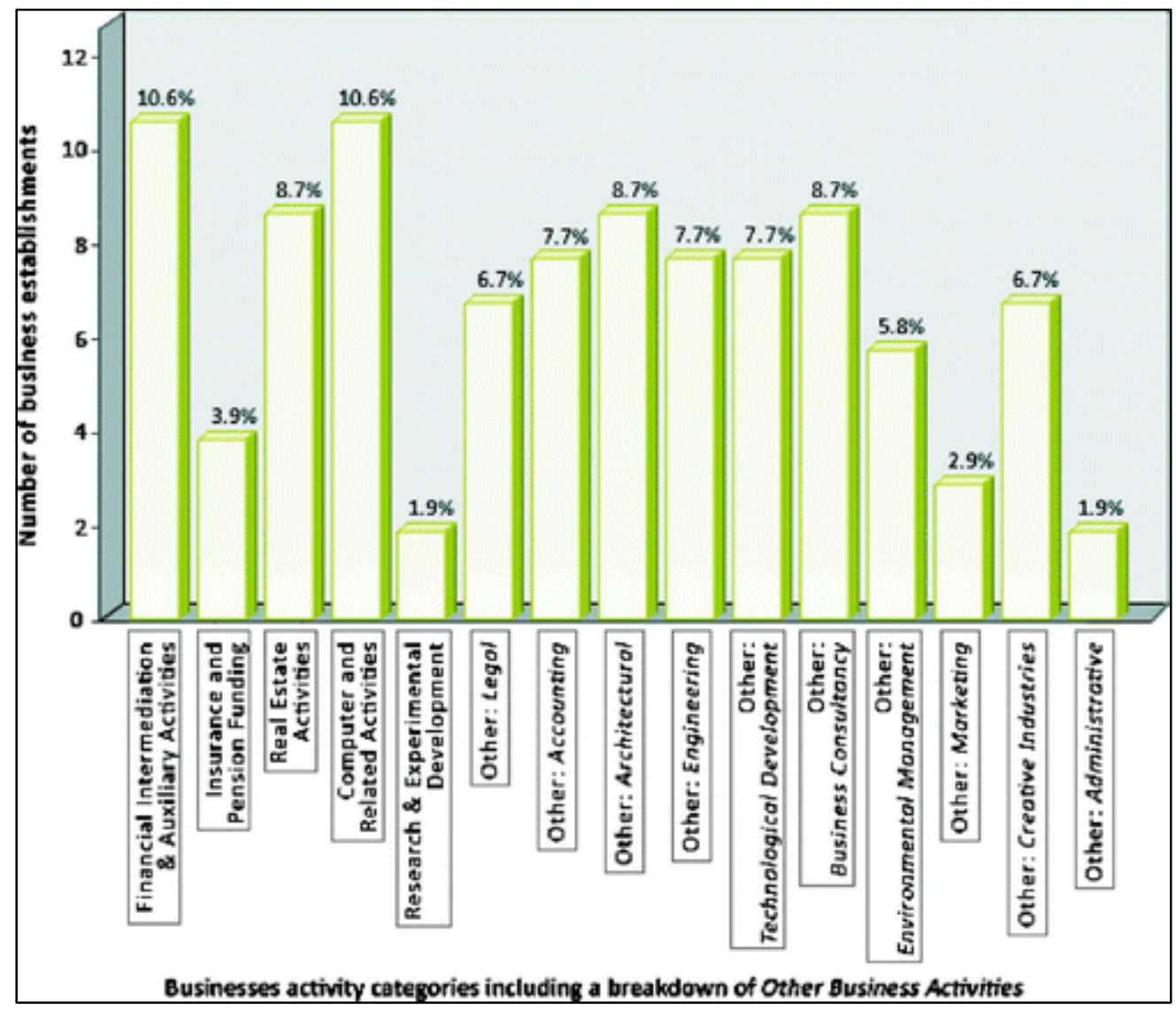

Figure 1: Distribution of Stellenbosch establishments across main business activity categories and Other Business Activities subcategories $(\mathrm{n}=104)$ 


\begin{tabular}{|c|c|c|c|c|c|c|}
\hline \begin{tabular}{|l} 
Year of \\
establishment
\end{tabular} & $\begin{array}{l}\text { Single } \\
\text { branch }\end{array}$ & $\begin{array}{c}\text { National } \\
\text { branch }\end{array}$ & \begin{tabular}{|c|}
$\begin{array}{c}\text { National head } \\
\text { office }\end{array}$ \\
\end{tabular} & $\begin{array}{c}\text { International } \\
\text { branch }\end{array}$ & $\begin{array}{c}\text { International head } \\
\text { office }\end{array}$ & Total \\
\hline 2007 & 1 & 1 & 0 & 0 & 0 & 2 \\
\hline 2004-06 & 7 & 1 & 1 & 1 & 3 & 13 \\
\hline $2000-03$ & 15 & 7 & 4 & 1 & 2 & 28 \\
\hline \begin{tabular}{|l|}
$1994-99$ \\
\end{tabular} & 27 & 3 & 3 & 0 & 2 & 35 \\
\hline \multirow[t]{2}{*}{ Before 1994} & 15 & 3 & 3 & 3 & 1 & 25 \\
\hline & 65 & 15 & 11 & 5 & 8 & 104 \\
\hline
\end{tabular}

Table 1: Length of time different branch types have been operational in Stellenbosch $(n=104)$

\begin{tabular}{|l|l|l|l|l||l||}
\hline \hline Factor & $\begin{array}{c}\text { Crucial to } \\
\text { business's success }\end{array}$ & Important & Necessary & $\begin{array}{c}\text { Beneficial but not } \\
\text { necessary }\end{array}$ & $\begin{array}{c}\text { Not } \\
\text { important }\end{array}$ \\
\hline $\begin{array}{l}\text { A highly educated } \\
\text { workforce }\end{array}$ & $53 \%$ & $36 \%$ & $7 \%$ & $2 \%$ & $2 \%$ \\
\hline $\begin{array}{l}\text { Face-to-face client } \\
\text { consultation }\end{array}$ & $58 \%$ & $25 \%$ & $9 \%$ & $5 \%$ & $15 \%$ \\
\hline Proximity to clients & $16 \%$ & $33 \%$ & $13 \%$ & $24 \%$ & $7 \%$ \\
\hline $\begin{array}{l}\text { The latest information } \\
\text { technology (IT) }\end{array}$ & $39 \%$ & $36 \%$ & $13 \%$ & $12 \%$ & $13 \%$ \\
\hline $\begin{array}{l}\text { Research \& development } \\
\text { R\&D) }\end{array}$ & $30 \%$ & $24 \%$ & $22 \%$ & $17 \%$ & $20 \%$ \\
\hline Inter-firm networks & $24 \%$ & $27 \%$ & $21 \%$ & $15 \%$ & $5 \%$ \\
\hline $\begin{array}{l}\text { Convenient transport } \\
\text { infrastructure }\end{array}$ & $12 \%$ & $26 \%$ & $18 \%$ & $5 \%$ \\
\hline Proximity to competitors & $6 \%$ & $17 \%$ & $4 \%$ & $19 \%$ \\
\hline
\end{tabular}

Table 2: Factors contributing to the successful performance of core business activities 


\begin{tabular}{|c|c|c|c|c|}
\hline $\begin{array}{l}\text { Overall } \\
\text { ranking }\end{array}$ & Factors specific to Stellenbosch & Crucial & Beneficial & $\begin{array}{c}\text { Not } \\
\text { important }\end{array}$ \\
\hline 1 & This is/was the owner/key role player's hometown & $45 \%$ & $40 \%$ & $15 \%$ \\
\hline 2 & Beautiful natural surroundings & $15 \%$ & $57 \%$ & $28 \%$ \\
\hline 3 & A better quality of life for employees & $15 \%$ & $54 \%$ & $30 \%$ \\
\hline 4 & $\begin{array}{l}\text { The location attracts highly educated/specialist } \\
\text { employees }\end{array}$ & $16 \%$ & $51 \%$ & $32 \%$ \\
\hline 4 & $\begin{array}{l}\text { Good primary/secondary/tertiary education } \\
\text { opportunities for employees' children }\end{array}$ & $19 \%$ & $47 \%$ & $34 \%$ \\
\hline 5 & $\begin{array}{l}\text { losest location to the business's most important } \\
\text { clients/customers }\end{array}$ & $23 \%$ & $34 \%$ & $42 \%$ \\
\hline 6 & Closest location to the majority of the business's clients & $21 \%$ & $38 \%$ & $42 \%$ \\
\hline 6 & Close to Cape Town & $11 \%$ & $58 \%$ & $31 \%$ \\
\hline 7 & $\begin{array}{l}\text { A good location for finding highly skilled university } \\
\text { graduates }\end{array}$ & $19 \%$ & $41 \%$ & $40 \%$ \\
\hline 8 & $\begin{array}{l}\text { An excellent pool of highly educated specialists in } \\
\text { your line of business }\end{array}$ & $16 \%$ & $43 \%$ & $41 \%$ \\
\hline 8 & Safer than other areas in terms of crime & $13 \%$ & $50 \%$ & $37 \%$ \\
\hline 9 & $\begin{array}{l}\text { The business is situated close to useful business } \\
\text { networks }\end{array}$ & $8 \%$ & $58 \%$ & $34 \%$ \\
\hline 10 & $\begin{array}{l}\text { The business is situated at a prestigious address/office } \\
\text { park }\end{array}$ & $16 \%$ & $40 \%$ & $44 \%$ \\
\hline 11 & A good mix of social and cultural amenities & $10 \%$ & $51 \%$ & $39 \%$ \\
\hline 12 & An attractive/suitable climate & $10 \%$ & $49 \%$ & $41 \%$ \\
\hline 13 & $\begin{array}{l}\text { The business is situated close to tertiary institutions } \\
\text { (excluding the university) }\end{array}$ & $13 \%$ & $39 \%$ & $48 \%$ \\
\hline 14 & A university town & $12 \%$ & $35 \%$ & $53 \%$ \\
\hline 14 & Close to convenient transport links & $11 \%$ & $36 \%$ & $53 \%$ \\
\hline 15 & Good public services & $5 \%$ & $32 \%$ & $63 \%$ \\
\hline 16 & $\begin{array}{l}\text { The business is situated close to R\&D institutions (e.g. } \\
\text { CSIR) }\end{array}$ & $8 \%$ & $24 \%$ & $68 \%$ \\
\hline 16 & $\begin{array}{l}\text { The business is situated close to similar firms in the } \\
\text { same industry (competitors) }\end{array}$ & $5 \%$ & $30 \%$ & $65 \%$ \\
\hline 17 & Certain other financial benefits & $6 \%$ & $23 \%$ & $71 \%$ \\
\hline 18 & $\begin{array}{l}\text { The business is situated close to useful government } \\
\text { resources }\end{array}$ & $1 \%$ & $31 \%$ & $68 \%$ \\
\hline 19 & Rent benefits & $1 \%$ & $17 \%$ & $82 \%$ \\
\hline 20 & Tax benefits & $1 \%$ & $10 \%$ & $89 \%$ \\
\hline
\end{tabular}

Table 3: Factors influencing business location 


\begin{tabular}{|c|c|c|c|c|c|}
\hline \multirow[b]{2}{*}{$\begin{array}{l}\text { Business branch } \\
\text { types }\end{array}$} & \multicolumn{5}{|c|}{ Average percentage of clients at different locations } \\
\hline & Stellenbosch & $\begin{array}{c}\text { Surrounding small } \\
\text { towns }\end{array}$ & $\begin{array}{l}\text { Cape } \\
\text { Town }\end{array}$ & $\begin{array}{c}\text { Other } \\
\text { provinces }\end{array}$ & $\begin{array}{c}\text { Other } \\
\text { countries }\end{array}$ \\
\hline Single branches & $41 \%$ & $19 \%$ & $16 \%$ & $18 \%$ & $6 \%$ \\
\hline National branch & $23 \%$ & $36 \%$ & $17 \%$ & $18 \%$ & $3 \%$ \\
\hline National head office & $12 \%$ & $17 \%$ & $17 \%$ & $52 \%$ & $3 \%$ \\
\hline International branch & $30 \%$ & $24 \%$ & $5 \%$ & $1 \%$ & $40 \%$ \\
\hline $\begin{array}{l}\text { International head } \\
\text { office }\end{array}$ & $8 \%$ & $6 \%$ & $9 \%$ & $11 \%$ & $65 \%$ \\
\hline
\end{tabular}

Table 4: Geographic distribution of client base per branch type 
1. Amin, A and Cohendet, P. 2005. Geographies of knowledge formation in firms. Industry and Innovation, 12(4): 465-86.

2. Amin, A and Thrift, N. 2002. "Cities: Rethinking Urban Theory". Cambridge: Polity Press.

3. Angelis, V, Mavri, M, Gaki, E and Koufodontis, I. 2007. "The role of universities on regional development regional well-being". Unpublished paper, Department of Business Administration, University of the Aegean

4. Anselin, L, Varga, A and Acs, Z. 2000. Geographical spillovers and university research: A spatial econometric perspective. Growth and Change, 31: 501-15.

5. Aslesen, $\mathrm{H} \mathrm{W}$ and Isaksen, $\mathrm{H}$. Knowledge intensive business services and urban-industrial development. Paper delivered at the 14th International Conference of RESER (European Association for Research on Services). Mons, France. Do KIBS [knowledge intensive business services] cause increased geographic concentration of industries?, http://reser.net/index.php?action=telechargement\&classeur_444 Accessed 15 September 2007

6. Aslesen, H W and Jakobsen, S E. 2007. The role of proximity and knowledge interaction between head offices and KIBS. Tijdschrift voor Ekonomische en Sociale Geografie, 98(2): 188201.

7. Bale, J. 1981. "The Location of Manufacturing Industry”. Edinburgh: Oliver \& Boyd.

8. Beyers, W B and Lindahl, D P. 1996. Lone eagles and high fliers in rural producer services. Rural Development Perspectives, 11: 2-10.

9. Borja, J and Castells, M. 1997. "Local and Global: The Management of Cities in the Information Age". London: Earthscan.

10. Bryson, J R, Rusten, G and Gammelsæter, H. Road warriors and homelurkers in a developed market economy: Virtual and weightless organisational forms in the regional production and consumption of management consultancy expertise and knowledge in Norway. Paper delivered at the 13th international conference of RESER (European Association for Research on Services). Mons, France. http://reser.net/index.php?action=telechargement\&classeur_444 Accessed 10 September 2007

11. Bryson, J R, Daniels, P W and Warf, B. 2004. "Service Worlds: People, Organisations, Technologies". London: Routledge.

12. Castells, M. 1991. “The Informational City: Information Technology, Economic Restructuring and the Urban-Regional Process". Oxford: Blackwell.

13. Castells, M. 1998. "The Information Age: Economy, Society and Culture". In Volume 3 - End of Millennium, Malden, MA: Blackwell Business.

14. Castells, M. 2000. The Rise of the Network Society. 2nd edn, Oxford: Blackwell.

15. Clark, J. 2010. Coordinating a conscious geography: The role of research centers in multi-scalar innovation policy and economic development in the US and Canada. Journal of Technological Transfer, 35: 460-74.

16. Coffey, W J. 1995. Producer services research in Canada. Professional Geographer, 47: 74-81.

17. Coffey, W J and Shearmur, R G. 1997. The growth and location of high order services in the Canadian urban system, 1971-1991. Professional Geographer, 49: 404-18.

18. Cornelissen, S. 2006. "'Entrepreneurial regions?' The foreign relations of cities and provinces in South Africa". In South African Foreign and Security Policies in the Post-Apartheid Era, Edited by: Carlsnaes, W, Geldenhuys, D and Nel, P. 125-36. Aldershot: Ashgate.

19. Daniels, P W. 1993. "Service Industries in the World Economy". Oxford: Blackwell.

20. Daniels, P W and Bryson, J R. 2002. Manufacturing services and servicing manufacturing: Knowledge-based cities and changing forms of production. Urban Studies, 39: 977-91. 
21. Daniels, P W and Bryson, J R. Business and professional services in a second city region: Linking local to global?. Paper delivered at the 13th International Conference of RESER (European Association for Research on Services). Mons, France.

http://reser.net/index.php?action=telechargement\&classeur_444 Accessed 10 September 2007

22. Florida, R. 1999. The role of the university: Leveraging talent, not technology. Issues in Science and Technology, 15: 67-73.

23. Florida, R. 2005. "Cities and the Creative Class". London: Routledge.

24. Harloe, M and Perry, B. 2004. Universities, localities and regional development: The emergence of the 'mode 2' university. International Journal of Urban and Regional Research, 28: 212-23.

25. Harrison, P. 1994. Global economic trends: Some implications for local communities in South Africa. Urban Forum, 5: 73-89.

26. Klaus, P. 2004. Urban settings in the competition among cities. Revista Theomai, http://revistatheomai.unq.edu.ar/numero9/artklauss9.htm Accessed 24 July 2007

27. Lawton Smith, H, Keeble, D, Lawson, C, Moore, B and Wilkinson, F. 2001. University-business interaction in the Oxford and Cambridge regions. Tijdschrift voor Ekonomische en Sociale Geografie, 92: 88-99.

28. Lősch, A. 1954. “The Economics of Location”. New Haven, CT: Yale University Press.

29. Lublinski, A E. 2004. Does geographic proximity matter? Evidence from clustered and nonclustered aeronautic firms in Germany. Regional Studies, 37: 453-67.

30. Manuel, T A. The South African tax reform experience since 1994. Address delivered at the annual conference of The International Bar Association. 20-25 October, Durban.

31. Park, S O. 2001. Regional innovation strategies in the knowledge-based economy. GeoJournal, 53: 29-38.

32. Porter, M. 1998. Clusters and the new economics of competition. Harvard Business Review, 76: 77-90.

33. Riddle, D. 1986. "Service-led Growth: The Role of the Service Sector in World Development". New York: Praeger.

34. Rogerson, C M. 2000. Local economic development in an era of globalisation: The case of South African cities. Tijdschrift voor Ekonomische en Sociale Geografie, 91: 397-411.

35. Rogerson, C M. 2001. Knowledge-based or smart regions in South Africa. South African Geographical Journal, 83: 34-47.

36. Rogerson, C M. 2002. "Knowledge-based regions in the global periphery: The case of South Africa". In Knowledge, Industry and Environment: Institutions and Innovation in Territorial Perspective, Edited by: Hayter, R and Le Heron, R. 313-35. Aldershot: Ashgate.

37. SADC (Southern African Development Community), 2006. SADC trade, industry and investment review 2006. www.sadcreview.com/country_profiles/southafrica/southafrica.htm Accessed 20 October 2007.

38. Shearmur, R and Doloreux, D. 2007. "Urban hierarchy or local milieu? High-order producer service and (or) knowledge intensive business service location in Canada, 1991-2001". In Innovation Systems Research Network www.utoronto.ca/isrn/publications/WorkingPapers/index.html Accessed 31 July 2007

39. Stellenbosch Municipality. 2007. "Integrated Development Plan (IDP)". Stellenbosch: Stellenbosch Municipality.

40. The Presidency Republic of South Africa. 2006. "National Spatial Development Perspective (NSDP)". Pretoria: Policy Coordination and Advisory Service.

41. Uyarra, E. 2010. What is evolutionary about 'regional systems of innovation'? Implications for regional policy. Journal of Evolutionary Economics, 20: 115-37. 
42. Van der Merwe, I J, Davids, A J, Ferreira, S, Swart, G P and Zietsman, H L. 2004. "Growth Potential of Towns in the Western Cape. Centre for Geographical Analysis,". University of Stellenbosch.

43. Van Niekerk, A, Donaldson, R, Du Plessis, D J and Spocter, M. 2011. "A revision of the 2004 Growth Potential of Towns in the Western Cape study". Centre for Geographical Analysis, University of Stellenbosch.

44. Varga, A. 2002. "Knowledge transfers from universities and the regional economy: A review of the literature". In Unpublished report, Hungary: Department of Economics, University of Pécs.

45. WCPG (Western Cape Provincial Government). 2006. "The provincial growth and development strategy (PGDS) which serves as a green paper for the Western Cape, P.N. 306 of 2006". In Provincial Gazette Extraordinary 6385, 4.10.2006

46. World Bank. 2008. "Knowledge Economy Index (KEI) and Knowledge Index (KI)". www.worldbank.org/kam Accessed 29 May 2012

47. Yigitcanlar, T, O'Conner, K and Westerman, C. 2008. The making of knowledge cities: Melbourne's knowledge-based urban development experience. Cities, 25: 63-72. 